\title{
Pengaruh Modal Kerja Terhadap Penjualan dan Laba Bersih Pada Perusahaan Sub Sektor Food and Beverages Yang Terdaftar di Bursa Efek Indonesia Periode 2013-2017
}

\author{
Atin Ari Mawar Astuti ${ }^{1}$, Andria Referli ${ }^{2}$, Milka Susana Theorupun ${ }^{3}$ \\ atinmawar14@gmail.com \\ Universitas Boyolali
}

\begin{abstract}
In the activities of a company, the main problem is working capital. Working capital is the capital used to run a company's operations. Because without sufficient working capital, the company will experience a financial crisis and the most worrying is bankruptcy.

This research aims to knowing the effect of working capital on sales and net income in the Food and Beverages sub-sector companies listed on Indonesia Stock Exchange 2013-2017.

The type of data used is secondary data, that is about financial statements. Sampling technique used purposive sampling as much 12 company's. All data analyzed with classic assumption test, simple linear regression analysis, $t$ test, determination coefficient. Research result indicate with significant level 0.05 that working capital has a positive effect on sales and net income.
\end{abstract}

Keyword : Working Capital, Sales, Net Income

\section{PENDAHULUAN}

\subsection{Latar Belakang}

Setiap perusahaan selalu membutuhkan dana untuk membiayai operasinya seharihari, misalkan untuk memberikan persekot pembelian bahan mentah, membayar upah buruh, gaji pegawai, dan lain sebagainya. Dana yang telah dikeluarkan diharapkan akan dapat kembali lagi masuk dalam perusahaan dengan waktu yang pendek melalui hasil penjualan produksinya. Para manajer diharapkan memahami bagaimana cara menciptakan suatu sistem pengelolaan modal kerja yang efektif dan efisien, sehingga apa yang menjadi sasaran dari aktivitas produksi yang dilakukan akan tercapai dan laba yang diperoleh sesuai dengan keinginan perusahaan (Adi Zulfikar, 2012).

Modal kerja yang besar mencerminkan bahwa kegiatan usaha suatu perusahaan meningkat, yang dapat terlihat dari meningkatnya penjualan yang diperoleh (Adi Zulfikar, 2012).Tujuan akhir dari peningkatan penjualan yang dilakukan oleh perusahaan yaitu diharapkan akan berdampak pada laba bersih yang terus meningkat. Laba merupakan hasil dari seluruh kegiatan perusahaan yang telah 
dijalankan sebelumnya melalui proses perencanaan serta pengendalian dari seluruh kegiatan perusahaan.

Perusahaan Food and Beverages dipilih karena memiliki peranan penting dalam memenuhi kebutuhan konsumen. Kebutuhan masyarakat pada produk makanan dan minuman akan selalu ada, karena merupakan salah satu kebutuhan pokok. Didasarkan pada kenyataan tersebut, perusahaan makanan dan minuman masih berkontribusi dalam industri di Indonesia.

Pengelolaan modal kerja sangat penting dalam bidang keuangan karena kesalahan dan keliruan dalam mengelola modal kerja dapat mengakibatkan kegiatan usaha menjadi terhambat atau bisa terhenti. Indikator modal kerja yang baik adalah modal kerja yang setiap tahun mengalami kenaikkan dan dimana jumlah assets lancar harus lebih besar dari hutang lancar, sehingga menggambarkan adanya tingkat keamanan (margin safety) yang memuaskan. Oleh karena itu, modal kerja sangat penting dan dibutuhkan oleh perusahaan dalam kegiatan operasionalnya sehari-hari. Berdasarkan latar belakang yang telah dikemukan maka penulis tertarik untuk mengambil judul penelitian

"Pengaruh

Modal

Kerja Terhadap Penjualan

dan Laba Bersih Pada Perusahaan Sub Sektor Food and Beverages yang Terdaftar di Bursa Efek Indonesia Periode 2013-2017".

\section{TINJAUAN PUSTAKA}

\subsection{Landasan Teori} Pengetian Industri

Pengertian industri menurut Undang - Undang Republik Indonesia No. 3 Tahun 2014 tentang perindustrian. Industri adalah seluruh bentuk kegiatan ekonomi yang mengolah bahan baku dan/atau memanfaatkan sumber daya industri sehingga menghasilkan barang yang mempunyai nilai tambah atau manfaat lebih tinggi termasuk jasa industri.

\section{Modal Kerja}

\begin{tabular}{llr}
\multicolumn{1}{c}{ Menurut } & & Kasmir \\
$(2016: 250)$ & modal & kerja \\
merupakan & modal & yang
\end{tabular}
digunakan untuk melakukan kegiatan operasi perusahaan. Modal kerja diartikan sebagai investasi yang ditanamkan dalam aktiva lancar atau aktiva jangka pendek, seperti kas, bank, suratsurat berharga, piutang, persediaan dan aktiva lancar. Modal kerja dalam bentuk kas, surat berharga, piutang dagang, untuk membiayai kegiatan operasi tersebut diharapkan dapat masuk kembali ke perusahaan dalam jangka waktu yang pendek, agar dana tersebut, selanjutnya dapat digunakan lagi untuk kegiatan operasi.

\section{Penjualan}

Menurut Basu Swastha (2014:197) penjualan merupakan penjualan bersih dari laporan rugi-laba perusahaan (laporan operasi). Menurut mulyadi (2013:202), yaitu "penjualan merupakan kegiatan yang dilakukan oleh penjual dalam 
menjual barang atau jasa dengan harapan akan memperoleh laba dari adanya transaksi-transaksi tersebut dan penjualan dapat diartikan sebagai pengalihan atau pemindahan hak kepemilikan atas barang atau jasa dari pihak ke pembeli.

\section{Laba}

L.M. Samryn (2012:429), menyatakan bahwa pengertian laba adalah sebagai berikut: "Laba merupakan sumber dana internal yang dapat diperoleh dari aktivitas normal perusahaan yang tidak membutuhkan biaya ekstra untuk penyimpanan dan penggunaannya".Sedangkan menurut Wild dan Subramanyam (2014:25), menyatakan bahwa pengertian laba adalah sebagai berikut: "Laba (earnings) atau laba bersih (net income) mengindikasikan profitabilitas perusahaan. Laba mencerminkan pengembalian kepada pemegang ekuitas untuk periode bersangkutan, sementara pos-pos dalam laporan merinci bagaimana laba didapat".

\subsection{Kerangka Pemikiran}

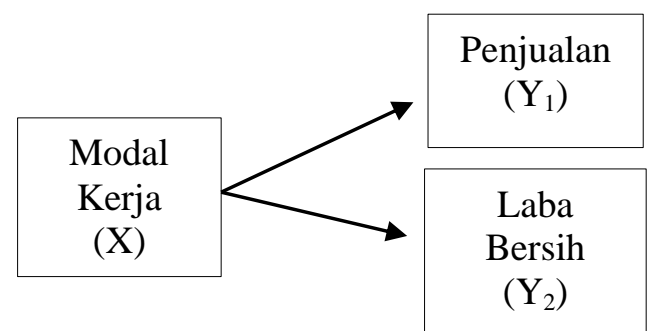

Hipotesis 2 : Modal kerja berpengaruh positif terhadap laba bersih.

\section{METODOLOGI PENELITIAN}

Berdasarkan jenis data yang digunakan, penelitian ini merupakan penelitian kuantitatif dengan pendekatan penelitian deskriptif dan analisis verifikatif, karena menganalisa pengaruh variabel independen terhadap variabel dependen. Metode pengumpulan data yang digunakan dalam penelitian adalah dengan riset internet (research online) yang diperoleh melalui situs resmi Bursa Efek Indonesia yaitu http://www.idx.co.id. Data yang digunakan dalam penelitian ini adalah data sekunder dari laporan keuangan. Teknik analisa yang digunakan dalam penelitian ini adalah uji asumsi klasik, uji regresi linier sederhana, uji $\mathrm{t}$ dan uji koefisien determinasi.

\section{PENGUJIAN HIPOTESIS}

Hasil analisis data diatas menghasilkan nilai-nilai yang digunakan untuk membuktikan hipotesis dari penelitian, yaitu sebagai berikut:

1. Pengaruh Modal Kerja (X) Terhadap Penjualan $\left(\mathrm{Y}_{1}\right)$

\subsection{Hipotesis Penelitian}

Atas dasar pemikiran teoritik dan penelitian tersebut, hipotesis penelitian ini sebagai berikut:

Hipotesis 1: Modal kerja berpengaruh positif terhadap penjualan.

\begin{tabular}{|c|c|c|c|c|c|c|}
\hline & & & & Coefficients ${ }^{a}$ & & \\
\hline kerangk & Model & $\begin{array}{r}\text { Unstan } \\
\text { Coeff }\end{array}$ & $\begin{array}{l}\text { lardized } \\
\text { cients }\end{array}$ & \begin{tabular}{|c|} 
Standardized \\
Coefficients
\end{tabular} & $\mathrm{t}$ & Sig. \\
\hline $\mathrm{mod}$ & 33 & $\mathrm{~B}$ & Std. Error & Beta & & \\
\hline & $(\mathrm{C}$ & 436.132 & 840.577 & & .519 & .606 \\
\hline $\begin{array}{r}\text { mak } \\
\text { adala }\end{array}$ & $\begin{array}{l}\text { Modal } \\
\text { Kerja }\end{array}$ & 4.089 & .168 & .954 & $\begin{array}{r}24.32 \\
2\end{array}$ & .000 \\
\hline
\end{tabular}

a. Dependent Variable: Penjualan

Hasil uji t pengaruh modal kerja terhadap penjualan 
menujukkan nilai $t_{\text {hitung }}$ sebesar 24.322 dan $p$ value (Sig) sebesar 0.000 yang dibawah alpha 5\%. Artinya bahwa ada pengaruh yang positif antara modal kerja terhadap penjualan. Hasil penelitian ini dapat menerima hipotesis yang menyatakan "ada pengaruh yang positif antara modal kerja terhadap penjualan”.

2. Pengaruh Modal Kerja (X) Terhadap Laba Bersih $\left(\mathrm{Y}_{2}\right)$ Coefficientsa

\begin{tabular}{|c|c|c|c|c|c|}
\hline \multirow[t]{2}{*}{ Model } & \multicolumn{2}{|c|}{$\begin{array}{l}\text { Unstandardized } \\
\text { Coefficients }\end{array}$} & $\begin{array}{c}\text { Standardized } \\
\text { Coefficients }\end{array}$ & \multirow[t]{2}{*}{$\mathrm{t}$} & \multirow[t]{2}{*}{ Sig. } \\
\hline & $\mathrm{B}$ & Std. Error & Beta & & \\
\hline (Constant) & 58.110 & 73.638 & & .789 & .433 \\
\hline $1 \begin{array}{l}\text { Modal } \\
\text { Kerja }\end{array}$ & .308 & .015 & .940 & 20.895 & \\
\hline
\end{tabular}

Hasil uji t pengaruh modal kerja terhadap bersih menujukkan nilai $t_{\text {hitung }}$ sebesar 20.895 dan $p$ value (Sig) sebesar 0.000 yang dibawah alpha 5\%. Artinya bahwa ada pengaruh yang positif antara modal kerja terhadap laba bersih Hasil penelitian ini dapat menerima hipotesis yang menyatakan "ada pengaruh yang positif antara modal kerja terhadap laba bersih.

\section{PENUTUP}

\subsection{Kesimpulan}

Berdasarkan

hasil pembahasan tentang pengaruh modal kerja terhadap penjualan dan laba bersih pada perusahaan sub sektor food and beverages periode $2013-2017$ dapat disimpulkan sebagai berikut :

1. Berdasarkan hasil analisis regresi sederhana dengan uji $\mathrm{t}$ menunjukan nilai sig. $0,000<$ 0,05 bahwa modal kerja secara parsial berpengaruh secara positif terhadap penjualan dengan tingkat pengaruh yang terjadi sebesar 0.911 atau $91,1 \%$ dan sisanya $8,9 \%$ dipengaruhi oleh variabel lain yang tidak dimasukkan dalam penelitian ini. Hasil tersebut sejalan dengan penelitian Erlina Yunitasari Widyamukti dan B.Junianto Wibowo (2018) dengan hasil penelitian modal kerja berpengaruh terhadap penjualan. Modal kerja yang tersedia secara efektif digunakan untuk pembelian atau pengadaan barang untuk menunjang penjualan maupun untuk menghasilkan laba. Yang artinya semakin besar modal kerja, maka semakin besar jumlah pembelian atau pengadaan barang. Dengan demikian jumlah barang yang dijual juga akan semakin besar

2. Berdasarkan hasil analisis regresi sederhana dengan uji $\mathrm{t}$ menunjukan nilai sig. $0,000<$ 0,05 bahwa modal kerja secara parsial berpengaruh secara positif terhadap laba bersih dengan tingkat pengaruh yang terjadi sebear 0.883 atau $88,3 \%$ dan sisanya $11,7 \%$ dipengaruhi oleh variabel lain yang tidak dimasukkan dalam penelitian ini. Hasil tersebut sejalan dengan penelitian Erlina Yunitasari Widyamukti dan B.Junianto Wibowo (2018) dengan hasil penelitian, modal kerja berpengaruh terhadap laba bersih. Besarnya modal kerja akan menentukan besarnya penjualan dan laba perusahaan dalam arah yang sama.

\subsection{Saran}

Berdasarkan penelitian ini yang telah dilakukan dan 
kesimpulan diatas, adapun saransaran yang penulis dapat sampaikan kepada semua pihak, baik kepada perusahaan, investor maupun pihak-pihak yang terkait antara lain sebagai berikut :

1. Bagi perusahaan food and beverages, hasil penelitian ini diharpakan dapat dipergunakan untuk mempertimbangkan keputusan manajemen dalam memperbaiki kinerja keuangan perusahaan, khususnya terkait dengan modal kerja, penjualan dan laba bersih.

\section{DAFTAR PUSTAKA}

Adi Zulfikar, 2012. Pengaruh Modal Kerja Terhadap Laba Operasional (Studi Kasus pada PT Reksa Jaya

Agus Indriyo, Gitusudarno dan Basri. 2008. Manajemen Keuangan. Yogyakarta: BPFE

Atmodjo, M W. 2005. Restoran dan Segala Permasalahannya. Yogyakarta: Andi

Badan Pusat Statistik. 2002. Statistik Indonesia. Semarang

Bambang, Riyanto. 2011. DasarDasar Pembelajaran Perusahaan, Edisi Keempat Cetakan ketujuh. Yogyakarta: YBPFE UGM

Basu Swastha, Dhaemmesta. 2014 Manajemen Pemasaran Yogyakarta: BPFE

Bonatua Purwadi Sipahutar, 2016. Pengaruh Modal Kerja Terhadap Laba Bersih (Studi Kasus Pada CV. Mustika
2. Bagi investor, perlu diperhatikan pergerakan modal kerja, penjualan maupun laba sebelum mengambil keputusan berinvestasi pada saham -saham perusahaan yang go publik, terutama perusahaan food and beverages.

3. Bagi peneliti selanjutnya sebaiknya melakukan penelitian dengan periode pengamatan yang lebih lama, sehingga datadata yang akan dianalisis lebih banyak, serta menambah perusahaan pada sektor lain.

$\begin{array}{lr}\text { Tasikmalaya). } & \text { Skripsi. } \\ \text { Fakultas } & \text { Ekonomi } \\ \text { Universitas } & \text { Siliwangi }\end{array}$

Jaya). Skripsi. Program Studi Akuntansi. Sekolah Tinggi Ilmu Ekonomi dan Bisnis Perdana Mandiri. Purwakarta

Budiningsih, Asri. 2009. Belajar dan Pembelajaran. Jakarta: Rineka Cipta

Djarwanto. 2011. Pokok-Pokok Analisis Laporan Keuangan, Edisi Kedua. Yogyakarta: BPFE

Eva Ariesti, 2008. Pengaruh Volume Penjualan Buku Cetak Terhadap Peningkatan Laba Bersih. Semarang. Universitas Semarang

Erlina Yunitasari Widyamukti dan B. Junianto Wibowo , 2018. Pengaruh Modal Kerja Terhadap Penjualan dan Laba (Studi Kasus Pada 
Sektor Food and Beverages yang terdaftar di BEI 2011 2014). Program Studi Manajemen, Fakultas Ekonomi dan Bisnis. Universitas Katholik Soegijapranata. ISSN:2622612/Vol 1/No 1/April 2018

Ghozali, Imam. 2016. Aplikasi Analisis Multivariete Dengan Program IBM SPSS 23 (Edisi 8), Cetakan ke VII. Semarang: Badan Penerbit Universitas Diponegoro

Hendri, Ma'ruf. 2005. Manajemen Ritel. Jakarta: PT Gramedia Pustaka Utama

Jumingan. 2011. Analisis Laporan Keuangan. Jakarta: Bumi Aksara

Kasmir. 2011. Analisis Laporan Keuangan, Catatan Keempat.Jakarta: PT Raja Grafindo Persada

Kasmir. 2016. Analisis Laporan Keuangan. Jakarta: PT Raja Grafindo Persada

Moch,Nazir. 2011. Metode Penelitian, Cetakan ke 6. Bogor: Ghalia Indonesia

Mulyadi. 2013. Sistem Akuntansi, Edisi Ketiga, Cetakan Keempat. Jakarta: Salemba Empat

Munawir, S. 2010. Analisis Laporan Keuangan Edisi Keempat, Cetakan Kelima Belas. Yogyakarta: Liberty
Purwanti TJ, dkk. 1994. Manajemen Katering, Fakultas Pendidikan \&Tekno Kejuruan. Yogyakarta: Institut Keguruan \& Ilmu Pendidikan

Rahardjo, Budi. 2010. Keuangan dan Akuntansi Untuk Manajer non Keuangan. Yogyakarta: Graha Ilmu

Samryn, L.M. 2014. Pengantar Akuntansi Edisi IFRS. Jakarta: Rajawali Pers

Subramanyam, K.R dan John J. Wild. 2014. Analisis Laporan Keuangan, Penerjemah Dewi $Y$. Jakarta: Salemba Empat

Sugiyono. 2013. Metode Penelitian Pendidikan Pendekatan Kuantitatif, Kualitatif, Dan $R$ $\& D$. Bandung: Alfabeta

ıgiyono. 2014. Metode Penelitian Pendidikan Pendekatan Kuantitatif, Kualitatif, Dan $R$ $\& D$. Bandung: Alfabeta

Sugiyono. 2016. Metode Penelitian Pendidikan Pendekatan Kuantitatif, Kualitatif, Dan $R$ $\& D$. Bandung: Alfabeta

Sujarweni, Wiratna. 2015. SPSS untuk Penelitian. Yogyakarta: Pustaka Baru Pers

Supriyadi, Yoyon dan Fani Ratih Puspitasari, 2012. Pengaruh Modal Kerja Terhadap Penjualan dan Profitabilitas Perusahaan Pada PT 
Indocement Tunggal Perkasa Tbk. Jurnal Ilmiah Kesatuan. Vol 14: hal 71-80

Sonyya Nurman Sasongko, 2014. Pengaruh Modal Kerja dan Volume Penjualan Terhadap Laba Bersih (Studi Kasus Pada Perusahaan Industri Logam yang Terdaftar di BEI Tahun 2010-2012. Fakultas Ekonomi. Universitas Komputer Indonesia

Undang-Undang RI No. 3 Tahun 2014 tentang Perindustrian Lembaran Negara Republik Indonesia Tahun 2014 No. 4
Uyanto, S.S. 2006. Pedoman Analisis dengan SPSS. Yogyakarta: Graha Ilmu

Yovin, Devi dan Santi Suryantini Ni Putu. 2010. Faktor-Faktor yang Berpengaruh Terhadap Struktur Modal Pada Perusahaan Food and Beverages yang Terdaftar di Bursa Efek Indonesia. Fakultas Ekonomi. Universitas Udayana

Referensi melalui Riset Internet (Online Reseacrh)

www.kemenperin.go.id

$\underline{\text { www.idx.co.id }}$ 